\title{
Spontaneous intracranial hypotension with pituitary adenoma
}

\author{
Ahmet K. Firat · Hakki M. Karakas • \\ Yezdan Firat · Bayram Kahraman · \\ Gülnur Erdem
}

Published online: 22 February 2008

(C) Springer-Verlag 2008

Erratum to: J Headache Pain (2006) 7:47-50

DOI 10.1007/s10194-006-0269-3

Unfortunately the name of one of the authors was rendered incorrectly. Instead of "Zeynep Y. Firat", it should have been Yezdan Firat, as now shown here.

The online version of the original article can be found under doi:10.1007/s10194-006-0269-3.

\footnotetext{
A. K. Firat $(\bowtie) \cdot$ H. M. Karakas - B. Kahraman - G. Erdem Department of Radiology, Inonu University Medical Faculty, Turgut Ozal Medical Center, Malatya, Turkey

e-mail: akfirat@inonu.edu.tr

Y. Firat

Department of Otorhinolaryngology,

Inonu University Medical Faculty,

Turgut Ozal Medical Center, Malatya, Turkey
} 